\title{
DISKUALIFIKASI PASANGAN CALON BUPATI DAN WAKIL BUPATI BANGKALAN MADURA PERSPEKTIF FIKIH SIYASAH
}

\author{
Rahmat \\ PT Valda Sumber Daya Mandiri, Jl. Dr. Soeomo Surabaya | rahmatilahil8@gmail.com
}

\begin{abstract}
This article discusses about the disqualification of the candidate of regent and vice regent in Bangkalan-Madura within the Islamic political jurisprudence perspective. In a decision No. 136/G/2012/PTUN.Sby, the Surabaya State Administrative Court decided that regent and vice regent in Bangkalan-Madura, which is signed by the leader of the National Unity Party (PPN), is legally flawed on the basis of article I, paragraph 12, article 57 paragraph 3 of Regulation of KPU No. 6 year 2011. The decision is by the consideration that the National Unity Party is not a new party. It is just changing the name of the Regional Unity Party that should remain as chairman and secretary of the DPC PPN of Bangkalan-Madura. The judge of the Surabaya State Administrative Court within his legal decision No. 136/G/2012/PTUN.Sby set the proposal of the regent and vice regent in Bangkalan-Madura.
\end{abstract}

Keywords: Disqualification, candidates, regent, Islamic jurisprudence.

Abstrak: Artikel ini membahas tentang diskualifikasi Calon Bupati dan Wakil Bupati di Bangkalan-Madura perspektif fikih Siyasah. Dalam putusan Nomor: 136/G/2012/PTUN.Sby, Pengadilan Tata Usaha Negara Surabaya memutuskan usulan Cabup Cawabup Kabupaten Bangkalan-Madura yang ditandatangani oleh pimpinan Partai DPC Partai Persatuan Nasional adalah cacat hukum dengan dasar Pasal I angka 12 Pasal 57 ayat (3) Peraturan KPU No. 6 Tahun 201।. Keputusan tersebut berdasarkan pertimbangan Partai Persatuan Nasional yang bukan partai baru. Hanya merubah nama Partai Persatuan Daerah yang seharusnya tetap sebagai ketua dan sekretaris DPC PPN Bangkalan-Madura. Hakim PTUN Surabaya dalam putusan No. 136/G/2012/PTUN.Sby menetapkan pengajuan Cabup Cawabup Kabupaten Bangkalan-Madura.

Kata Kunci: Diskualifikasi, calon, bupati, fikih, siyâsah. 


\section{Pendahuluan}

Reformasi di bidang hukum dan ketatanegaraan Republik Indonesia secara makro berimbas pada tingkat dibawahnya yaitu pemerintahan daerah. Melalui Pasal 18 ayat (4) hasil amandemen UUD 1945 telah meletakkan dasar hukum yang jelas bagi pelaksanaan dan mekanisme pemerintahan di daerah, terutama pemerintahan Kepala Daerah dan Wakil Kepala Daerah. ${ }^{1}$ Reformasi dilaksanakan di berbagai bidang untuk menciptakan pemerintahan yang memiliki legitimasi, demokratis, jujur, bersih dan berwibawa. ${ }^{2}$

Pemilihan Kepala Daerah dan Wakil Kepala Daerah secara langsung pada dasarnya merupakan suatu proses politik bangsa menuju kehidupan yang lebih demokratis (kedaulatan rakyat), transparan, dan bertanggung jawab. ${ }^{3}$ Selain itu, pemilihan kepala daerah secara langsung merupakan sebuah produk kebijakan negara yang menjadi momentum politik besar yang saat ini dinilai dan diharapkan oleh pemerintah dan seluruh bangsa Indonesia sebagai pilihan dan jalan yang tepat untuk menuju demokrasi daerah.

Menurut Mahkamah Konstitusi, dalam menjabarkan maksud "dipilih secara demokratis" dalam Pasal 18 ayat (4) UUD 1945 pembuat undang-undang telah memilih cara pemilihan kepala daerah secara langsung, maka sebagai konsekuensi logisnya, asasasas penyelenggaraan pemilihan umum harus tercermin dalam penyelenggaraan pemilihan daerah secara langsung yaitu langsung, umum, bebas, rahasia, jujur, adil (luber-jurdil). ${ }^{4}$

I Titik Triwulan T. Pemilihan Kepala Daerah Berdasarkan Undang-Undang No.32 Tahun 2004 dalam Sistem Pemilu Menurut UUD 1945, (Jakarta: Prestasi Pustaka Publisher, 2005), VI.

2 Haw. Widjaja, Otonomi Daerah dan Daerah Otonomi, (Jakata: PT. RajaGrafindo Persada, 2002), 88.

3 Titik Triwulan T. Kombespol. Ismu Gunadi Widodo. Hukum Tata Usaha Negara dan Hukum Acara Peradilan Tata Usaha Negara Indonesia, (Jakarta: Kencana Media Group, 201 I ), 237238.

4 Keputusan Mahkamah Konstitusi Tentang Putusan Perkara No. 072-073/PUU-II/2005 "Pengujian Undang-Undang Nomor 32 Tahun 2004 Tentang Pemerintahan Daerah Terhadap UUD 1945", 67. 
Pilkada sebetulnya merupakan alternatif untuk menjawab hiruk pikuk, gaduh, kisruh, dan jeleknya proses maupun hasil pilkada secara tidak langsung lewat DPRD dibawah UU Nomor 22 Tahun 1999. Pilkada langsung menjadi kebutuhan mendesak guna untuk mengoreksi segera mungkin segala kelemahan dalam pilkada pada masa lalu. Pilkada bermanfaat untuk menegakkan kedaulatan rakyat atau menguatkan demokrasi lokal, baik pada lingkungan pemerintahan (government) maupun lingkungn kemasyarakatan (civil society). ${ }^{5}$ Tujuan ideal pilkada langsung antara lain terpilihnya kepala daerah yang terpercaya, memiliki kemampuan, kepribadian, dan moral yang baik. ${ }^{6}$

Dalam rangka penyelenggaraan pemerintahan daerah diterapkan prinsip demokrasi. Sesuai dengan pasal 18 ayat (4) UUD 1945, kepala daerah dipilih secara demokratis. ${ }^{7}$ Dalam Pasal 3 huruf a Pasal 4 ayat (1) peraturan KPU No. 6 Tahun 2011 tentang pedoman teknis tata cara pencalonan pemilihan umum Kepala Daerah dan Wakil Kepala Daerah dan Pasal 59 ayat (1) huruf a dan ayat (2) UU No. 12 Tahun 2008 perubahan atas UU. No. 32 Tahun 2004 tentang Pemerintahan Daerah, menetapkan bahwa pasangan calon Kepala Daerah dan wakil Kepala Daerah dapat dicalonkan baik oleh partai politik atau gabungan partai politik. Partai politik atau gabungan partai politik itu merupakan peserta Pemilu yang memperoleh paling sedikit 15\% (lima belas perseratus) dari jumlah kursi di DPRD, dan atau memperoleh dukungan suara dalam Pemilu Legislatif paling sedikit 15\% (lima belas perseratus)

${ }^{5}$ Suharizal, Pemilukada Regulasi, Dinamika dan Konsep mendatang, (Jakarta: PT. RajaGrafindo Persada, 20I2), 37. Dalam Djohermansyah Djohan, "Pilkada, Jangan Ditunda", Artikel Media Indonesia, 10 januari 2005

${ }^{6}$ Ibid., 4 I.

${ }^{7}$ Lihat dalam bukunya Didik Supriyanto, Menjaga Independensi Penyelenggara Pemilu disertai Undang-Undang Nomor 22 Tahun 2007 Tentang Penyelenggara Pemilu, (Jakarta: Perludem, 2007), 81. 
dari akumulasi perolehan suara sah dalam pemilu anggota DPRD di daerah yang bersangkutan. ${ }^{8}$

Ada tiga hal yang perlu dipertimbangkan di dalam memilih pimpinan pemerintahan yang kemudian diharapkan akan menjadi pemimpin, yakni: kapabilitas, akseptabilitas serta kompatibilitas. Kapabilitas adalah gambaran kemampuan dari si pemimpin baik intelektual maupun moral, yang dapat dilihat dari catatan jejak (track record) pendidikannya maupun jejak sikap dan prilakunya selama ini. Pemimpin yang baik tidak akan muncul secara tibatiba, melainkan melalui suatu proses panjang. Sedangkan akseptabilitas adalah gambaran tingkat penerimaan pengikut terhadap kehadiran pemimpin. Kompatibilitas dimaksudkan sebagai kemampuan untuk menyesuaikan diri dengan kebijakan dari pemerintah tingkat atasnya dan mengakomodasikan kebijakan dari pemerintah tingkat bawahnya maupun tuntutan dari para pengikutnya. ${ }^{9}$

Secara yuridis pengaturan mengenai pencalonan Kepala Daerah dan Wakil Kepala Daerah diatur dalam Pasal 59 sampai dengan pasal 64 Undang-Undang Nomor 32 Tahun 2004. Dari beberapa pasal tersebut memberikan kewenangan yang sangat besar kepada KPUD dalam menerima pendaftaran, meneliti keabsahan persaratan pencalonan dan menetapkan pasangan calon, yang walaupun ada ruang bagi partai politik atau pasangan calon untuk memperbaiki kekurangan dalam persaratan administrasi,

Pasal 61 ayat (4) UU No. 32 Tahun 2004 yang telah dirubah dengan UU No.12 tahun 2008menyatakan bahwa penetapan dan pengumuman pasangan calon oleh KPUD bersifat final dan

\footnotetext{
${ }^{8}$ Lihat dalam bukunya Daniel S. Salossa, Mekanisme, Persyaratan, dan Tata Cara Pilkada Langsung Menurut Undang-Undang No. \#32 Th 2004 tentang Pemerintahan Daerah, (Yogyakarta: Media Pressndo, 2005), 46.

9 Sadu Wasistiono, Kapita Selekta Manajemen Pemerintahan Daerah, (Bandung: CV. Fokusmedia, 2003), 118.
} 
mengikat. ${ }^{10}$ Tetapi ada juga penetapan dan pengumuman pasangan calon oleh KPUD dapat digagalkan oleh ketua dan sekretaris partai politik yang merasa kepentingannya dirugikan yang pada akhirya penetapan itu digagalkan melalui pengadilan. Sebagaimana yang terjadi di Kabupaten Bangkalan Madura pasangan calon Kepala Daerah dan Wakil Kepala Daerah (Bupati dan Wakil Bupati) kandas ditengah perjalanan hanya 6 (enam) hari menjelang pemilu, Cabup Cawabup nomor urut satu K.H. Imam Buchori dan HR. Zainal Alim dicoret atau dicabut oleh Komisi Pemilihan Umum (KPU) Kabupaten Bangkalan atas putusan Pengadilan Tata Usaha Negara (PTUN) Surabaya Nomor 136/G/2012/PTUN.Sby. tanggal 5 Desember 2012, sehingga tidak dapat mengikuti tahap pemilihan umum dalam Pilkada Kabupaten Bangkalan.

Hal itu berwal dari internal kepengurusan partai yang mengusungnya yakni Partai Persatuan Daerah (PPD) yang berganti nama menjadi Partai Persatuan Nasional, antara pengurus lama dengan pengurus baru (ketua dan sekretaris) H.M. Mukhlis Alkomi, S. Pd. sebagai ketua dan Ahmad Rois sebagai sekretaris dari Partai Persatuan Daerah, (Pengurus lama) sedangkan dari pengurus baru Supardi sebagai ketua dan Husnan sebagai sekretaris dari Partai Persatuan Nasional, keduanya saling mengaku menjadi pengurus dan saling menunjukkan SK. Akhirnya H.M. Mukhlis Alkomi S. Pd. dan Ahmad Rois merasa dirinya dirugikan karena tidak merasa mengusung calon K.H Imam Buchori dan Zainal Alim mengajukan gugatan ke PTUN Surabaya dan PTUN memenangkan mereka. Atas dasar putusan PTUN Surabaya maka KPU Bangkalan akhirnya mendiskualifikasi pasangan Cabup Cawabup No. urut satu K.H Imam Buchori dan Zainal Alim. ${ }^{11}$

10 UU No. 12 Tahun 2008 tentang perubahan atas UU No. 32 tahun 2004 tentang Pemerintahan Daerah.

" Pengadilan Tata Usaha Negara Surabaya, Berkas Putusan Perkara Sengketa Tata Usaha Negara Nomor: 136/G/20/2/PTUN.SBY, 5 
Dari pemaparan di atas penulis ingin menganalisis prosedur pendaftaran Cabup Cawabup Kabupaten Bangkalan Madura serta menganalisis dasar hukum pertimbangan yang digunakan Hakim PTUN Surabaya dalam memutuskan perkara Nomor: 136/G/2012/PTUN Sby tentang diskualifikasi Cabup Cawabup Kabupaten Bangkalan Madura, serta bagaimana tinjau fiqh siyâsahnya.

\section{Prosedur Pengajuan Pasangan Calon Bupati Kab. Bangkalan Madura}

Pasangan Calon Bupati dan Wakil Bupati Nomor urut 1 (satu) K.H. Imam Buchori dan HR. Zainal Alim diusung oleh gabungan partai politik yaitu Partai Kebangkitan Nasional Ulama (PKNU) yang memiliki 5 (lima) kursi di DPRD Kabupaten Bangkalan dan Partai Persatuan Nasional (PPN) yang memiliki 2 (dua) kursi di DPRD Kabupaten Bangkalan. Sedangkan jumlah seluruh anggota DPRD di Kabupaten Bangkalan adalah berjumlah 45 (empat lima) orang, maka sarat minimal 15\% (lima belas perseratus) suara partai politik pengusung dibulatkan menjadi minimal 7 (tujuh) kursi di DPRD. Oleh karena jumlah kursi PKNU ditambah PPD (saat ini menjadi PPN) memiliki 7 (tujuh) kursi di DPRD Kabupaten Bangkalan, maka telah memenuhi persyaratan untuk mengusung calon bupati dan wakil Bupati Kabupaten Bangkalan. ${ }^{12}$

Dengan demikian proses pencalonan Calon Nomor Urut 1 (satu) K.H. Imam Buchori dan HR. Zainal Alim telah sesuai dengan Pasal 4 Pragraf 1 huruf a dan b Peraturan Komisi Pemilihan Umum (KPU) No. 6 Tahun 2011 dan Undang-Undang Nomor 12 Tahun 2008 tentang perubahan atas Undang-Undang Nomor 32 Tahun 2004 tentang Pemerintahan Daerah menetapkan bahwa Partai politik atau gabungan partai politik dapat mendaftarkan bakal pasangan calon, apabila memenuhi

\footnotetext{
12 Pengadilan Tata Usaha Negara Surabaya, Berkas Putusan Perkara Sengketa Tata Usaha Negara Nomor: 136/G/20/2/PTUN.SBY, 84-85.
}

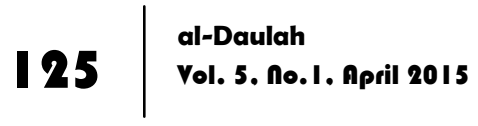


persyaratan memperoleh kursi pada Pemilu Anggota DPRD Tahun 2009 paling sedikit 15\% (lima belas perseratus) dari jumlah kursi DPRD yang bersangkutan; atau memperoleh suara sah pada Pemilu Anggota DPRD Tahun 2009 paling sedikit 15\% (lima belas perseratus) dari akumulasi perolehan suara sah dalam Pemilu Anggota DPRD di daerah yang bersangkutan. ${ }^{13}$

Calon Nomor urut 1 (satu) telah menindaklanjuti pengajuan dari PPN dan PKNU sebagai partai pengusung sesuai dengan tahapan Pilkada dan peraturan perundang-undangan yang berlaku yang selanjutnya dituangkan dalam Berita Acara Nomor:55/BA/X/2012 pada tanggal 22 Oktober 2012 tentang Penetapan Pasangan Calon Kepala Daerah dan Wakil Kepala Daerah Kabupaten Bangkalan Tahun 2012 dan Keputusan KPU Kabupaten Bangkalan Nomor 57/Kpts/KPUKab/014.329656/2012 tentang Penetapan Nomor Urut Pasangan Calon Kepala Daerah dan Wakil Kepala Daerah Sebagai Peserta Pemilihan Umum Kepala Daerah dan Wakil Kepala Daerah Kabupaten Bangkalan Tahun 2012 tanggal 24 Oktober 2012. Dan telah ikut melaksanakan tahapan Pilkada Kabupaten Bangkalan sebagaimana ketentuan perundang-undangan yang berlaku terutama telah melakukan kampanye yang telah mengeluarkan biaya yang tidak sedikit. ${ }^{14}$

Pasangan Cabup Cawabup nomor urut 1 (satu) mendaftar sebagai peserta Pilkada telah sesuai dengan mekanisme internal Partai Persatuan Nasional yang dibuktikan dengan dukungan dari DPC PPN Kabupaten Bangkalan, DPD PPN Provinsi Jawa Timur dan DPP PPN serta tidak ada calon lain yang diajukan oleh PPN sehingga secara hukum telah sesuai dengan ketentuan peraturan perundang-undangan yang berlaku.

\footnotetext{
${ }^{13}$ Peraturan KPU No. 6 Tahun 20 II Tentang Tata Cara Pencalonan Pemilihan Umum Kepela Daerah dan Wakil Kepala Daerah, dan UU No. 12 Tahun 2008 tentang perubahan atas UU No. 32 Tahun 2004 tentang Pemerintahan Daerah.

14 Mahkamah Konstitusi Republik Indonesia, Berkas Putusan Perkara Sengketa Perselisihan Hasil Pemilihan Umum Kepala Daerah dan Wakil Kepala Daerah Kabupaten Bangkalan Tahun 20/2 Nomor: 101/PHPUDX/2012,10.
} 
Sesuai surat Ketua DPC Partai Persatuan Nasional (DPC PPN) Kabupaten Bangkalan Nomor: 05/DPC-PPN/BKLN/2012 tanggal 02 Juli 2012, Perihal: Perubahan Nama Partai dan SK Perubahan DPC PPN yang dilampiri dengan: Copy Lembaran Negara RI No. 7 TAhun 2012; Copy Keputusan Menteri Hukum dan Ham Republik Indonesia, No. M.HH-04.AH.11.01 Tahun 2012, tentang Pengesahan Anggaran Dasar, Susunan Kepengurusan Partai Persatuan Daerah menjadi Paertai Persatuan Nasional Pereode 2011-2016; Copy Akte Notaris Perubahan Nama Partai; SK DPP PPN, No. 01/SK/DPP-PPN/K-K.16/VI/2012, tentang: Susunan Dewan Pimpinan Cabang Partai Persatuan Nasional (DPC PPN) Kabupaten Bangkalan, dengan Ketua Saudara Supardi dan Sekretaris Saudara Husnan Amd.

Pada tanggal 15 Agustus 2012, setelah PKNU dan PPN mendaftarkan pengesahan calon KH. Imam Buchori dan Zainal Alim sebagai Calon Bupat/Wakil Bupati Kabupaten Bangkalan, pasangan nomor urut 1 (satu) kedatangan tamu dari KPU Provinsi Jawa Timur untuk melakukan supervisi terkait dengan pelaksanaan jadwal, tahapan, dan program Pilkada termasuk didalamnya dalam melakukan verifikasi terhadap persyaratan pasangan calon bupati dan wakil bupati. Hasil dari supervisi tersebut yang terkait dengan perkara a quo adalah memutuskan bahwa berdasarkan peraturan KPU Nomor 6 tahun 2011 maka pencalonan yang diajukan oleh DPC PPN Kabupaten Bangkalan dinilai tidak memenuhi ketentuan pasal 4 peraturan KPU Nomor 6 Tahun 2011 karena DPC PPN Kabupaten Bangkalan bukan merupakan Partai Politik peserta pemilu tahun 2009 yang memiliki kursi/suara sah pada pemilu anggota DPRD tahun 2009. Berita acara tersebut KPU Provinsi menyatakan pendapatnya juga merupakan hasil konsultasi dengan KPU Rebuplik Indonesia.

Namun terkait dengan pendaftaran pasangan calon DPC PPN Kabupaten Bangkalan, pada tanggal 17 Agustus 2012 telah mengirim surat kepada KPU RI, dengan perihal surat: Mohon Petunjuk Perubaan Nama PPD menjadi PPN dalam Pilkada 
Kabupaten Bangkalan Tahun 2012. Kemudian pada tanggal 1 Oktober 2012 KPU RI telah memberikan jawaban tertulisnya yang diajukan kepada KPU Provinsi Jawa Timur, yang pada intinya menyatakan bahwa DPC PPN Kabupaten Bangkalan dapat mencalonkan pasangan calon bupati/wakil bupari Kabupaten Bangkalan. ${ }^{15}$

Namun keikutsertaan Calon Nomor Urut satu dalam Pilkada Kabupaten Bangkalan Tahun 2012 yang telah mengikuti seluruh tahapan Pilkada, (kecuali pemungutan suara) dibatalkan begitu saja oleh KPU yang hanya mendasarkan pada putusan Pengadilan Tata Usaha Negara (PTUN) Surabaya tanggal 5 Desember 2012. Dalam amar putusan PTUN Surabaya tersebut pada pokoknya menyatakan membatalkan Berita Acara Nomor 55/A/X/2012 tanggal 22 Oktober 2012 tentang Penetapan Pasangan Calon Kepala Daerah dan Wakil Kepala Daerah Kabupaten Bangkalan sepanjang tentang penetapan Pasangan Calon Bupati H.Imam Buchori dan Calon Wakil Bupati HR. Zainal Alim dan Keputusan KPU Kabupaten bangklan Nomor 57/Kpts/KPUKab/014/329656/2012 tentang Penetapan Nomor Urut Pasangan Kepala Daerah dan Wakil Kepala Daerah Kabupaten Bangkalan sepanjang tentang Penetapan Pasangan Calon Nomor Urut 1 (satu) atas nama H. Imam Buchori, SH dan H.R. Zainal Alim. ${ }^{16}$

Putusan PTUN Surabaya a quo tersebut didasarkan atas gugatan yang diajukan oleh H.M. Mukhlis Alkomi,S.Pd dan Ahmad Rois, yang keduanya mengaku sebagai Ketua dan Sekretaris DPC PPD (Partai Persatuan Daerah) Kabupaten Bangkalan padahal sebelum penggugat mengajukan gugatan kepada PTUN Surabaya Partai Persatuan Daerah telah berubah Anggaran Dasarnya, Anggaran Rumah Tangga, Nama, Lambang, Tanda Gambar dan Susunan Kepengurusan menjadi Partai

\footnotetext{
${ }^{15}$ Pengadilan Tata Usaha Negara Surabaya, Berkas Putusan Perkara Sengketa Tata Usaha Negara Nomor: 136/G/2012/PTUN.SBY, 21.

${ }^{16}$ Mahkamah Konstitusi Republik Indonesia, Berkas Putusan Perkara Sengketa Perselisihan Hasil Pemilihan Umum Kepal Daerah dan Wakil Kepala Daerah Kabupaten Bangkalan Tahun 2012 Nomor: 101/PHPUDX/2012., 9.
} 
Persatuan Nasional dan telah terjadi pergantian Kepengurusan DPC PPN Kabupaten Bangkalan berdasarkan Surat Keputusan Dewan Pimpinan Pusat Partai Persatuan Nasional, Nomor 01/SK/DPP-PPN/K-K.16/VI/2012, tentang sususnan Kepengurusan Dewan Pimpinan Cabang Partai Persatuan Nasional Kabupaten Bangkalan, Provinsi Jawa Timur, tanggal 14 Juni.

\section{Deskripsi Putusan Pengadilan Tata Usaha Negara Surabaya Nomor: 136/G/2012/PTUN. SBY Tentang Duduk Sengketa}

Kasus yang terdaftar pada PTUN Surabaya nomor registrasi: 136/G/2012/PTUN.Sby, pada dasarnya adalah kasus Sengketa Tata Usaha Negara, yang didalam petitum gugatannya melingkupi hak sebagai dewan Pimpinan cabang Partai Persatuan Daerah (PPD) yang berubah menjadi Partai persatuan Nasional (PPN) Kabupaten Bangkalan, yaitu antara H. M. Mukhlis Alkomi, S. Pd; Sebagai Ketua Partai Persatuan Daerah Kabupaten Bangkalan, tempat tinggal Jl. R. A. Kartini No. 24 Pongkeran Kraton Bangkalan dan Ahmad Rois sebagai Sekretaris Partai Persatuan Daerah Kabupaten Bangkalan, tempat tinggal Jl. R. A. Kartini No. 24 Pongkeran Kraton Bangkalan, dalam hal ini memberikan Kuasa Khusus kepada: Muhammad Sholeh, S.H; Imam Syafi'i, S.H; Abdul Holil, S.H; Ahmad Sahid, S.H; Adi Darmanto, S.H.

Kesemuanya berkewarganegaraan Indonesia, pekerjaan Advokat dan Advokat Magang, beralamat di Kantor Advokat Sholeh \& Partners, Jl Genteng Muhammadiyah No. 2 b, Surabaya Berdasarkan surat kuasa khusus tanggal 23 Oktober 2012; Selanjutnya disebut sebagai "Penggugat". ${ }^{17}$

Melawan Komosi Pemilihan Umum (KPU) Kabupaten Bangkalan, Berkedudukan di Jalan Pemuda Kaffa No. 1 Bangkalan dalam hal ini memberikan kuasa khusus kepada: Bakhtiar Pradinata, S.H., dan Fajar Harianto, S.H., advokat pada law Firm Tjakraningrat, berkedudukan di Perum Batara Regency Kav. 02 II.

17 Pengadilan Tata Usaha Negara Surabaya, Berkas Putusan Perkara Sengketa Tata Usaha Negara Nomor: 136/G/20/2/PTUN.SBY., I. 
Nusa Inda-Permuda Bangkalan. Berdasarkan Surat Kuasa Khusus tanggal 06 November 2012; selanjutnya disebut sebagai "Tergugat". ${ }^{18}$

Berdasarkan gugatan Penggugat pada tanggal 29 Oktober 2012, yang diterima dan didaftarkan di kepanitraan Pengadilan Tata Usaha Negara Surabaya, Penggugat mengemukakan bahwa Penggugat sampai saat ini adalah sebagai pengurus yang sah dari Partai Persatuan Daerah (PPD) Kabupaten Bangkalan periode 2008 samapi saat ini, tapi ternyata dalam perjalanan ada pihak yang mengaku sebagai pengurus cabang dari Partai Persatuan Nasional (perubahan dari Partai Persatuan Daerah) Kabupaten Bangkalan dengan mengusung Calon Bupati dan Wakil Bupati pasangan KH. Imam Buchori dan HR. Zainal Alim. Meskipun terjadi perubahan nama partai, akan tetapi di Kabuten Bangkalan tidak dilakukan pergantian pengurus, karena sampai sat ini tidak pernah ada SK pemberhentian.

Dalam proses pemilihan umum legislatif tahun 2009 yang diikuti oleh Penggugat, Penggugat memperoleh 2 (dua) kursi di DPRD Kabupaten Bangkalan, yaitu, HJ. Fathonah Rahcmanih, ST. MM dan Rokib, SE, kerugian yang diderita oleh Penggugat sangat besar dan signifikan, tidak hanya kerugian materil, energy dan pikiran tetapi hak-hak Penggugat sebagai partai yang mempunyai 2 (dua) kursi di DPRD Kabupaten Bangkalan seharusnya mendapatkan rasa keadilan dan kepastian hukum dalm proses pemilihan bupati dan wakil bupati Bangkalan priode 2013-2018, maka Penggugat memohon kepada Pengadilan Tata Usaha Negara Surabaya agar dinyatakan batal atau tidak sah surat keputusan tata usaha negara yang diterbitkan oleh Tergugat berupa:

1. Berita Acara Nomor : 55/BA/X/2012 tanggl 22 Oktober 2012 tentang Penetapan Pasangan Calon Kepala Daerah dan Wakil Kepala Daerah Kabupaten Bangkalan Tahun 2012 sepanjang tentang penetapan pasangan calon Bupati H. Imam Buchori

18 Pengadilan Tata Usaha Negara Surabaya, Berkas Putusan Perkara Sengketa Tata Usaha Negara Nomor: 136/G/20/2/PTUN.SBY., 2. 
(calon Bupati) dan HR. Zainal Alim (calon Wakil Bupati) yang diusung oleh Partai Kebangkitan Nasional Ulama (PKNU) dan Partai Persatuan Nasional perubahan nama dari Partai Persatuan Daerah (PPD)

2. Keputusan Komisi Pemilihan Umum Kabupaten Bangkalan Nomor: 57/kpts/KPU-Kab/014-329656/2012 tentang penetapan nomor urut pasangan calon Kepala Daerah dan wakil Kepala Daerah sebagai peserta pemilihan umum kepela daerah dan wakil kepala daerah Kabupaten Bangkalan Tahun 2012 sepanjang tentang penetapan pasangan nomor urut 1 (satu) calon Bupati dan Wakil Bupati H. Imam Buchori (calon Bupati) dan HR. Zainal Alim calon Wakil Bupati. Majelis Hakim Pengadilan Tata Usaha Negara Surabaya mengabulkan atas gugatan penggugat tersebu untuk sebagian, dan menyatakan batal dan mewajibkan mencabut Surat Keputusan Tata Usaha Negara yang diterbitkan oleh Tergugat, menghukum Tergugat untuk membayar biaya perkara sebesar Rp 152.500, (seratus Lima Puluh Dua Ribu Lima Ratus Rupiah)

\section{Dasar Hukum Pertimbangan Majelis Hakim Pengadilan Tata} Usaha Negara Surabaya dalam Memutuskan Perkara Nomor: 136/G2012/PTUN.SBY Tentang Sengketa Tata Usaha Negara

Majelis Hakim dalam memutuskan perkara tersebut mangacu pada pertimbangan bahwa secara subtansi Partai Persatuan Nasional bukanlah partai baru melaikan perubahan nama dari Partai Persatuan Daerah yang telah mengikuti Pemilu Anggota DPRD Tahun 2009 dan bersama PKNU yang juga peserta Pemilu Anggota DPRD Tahun 2009 dengan memiliki 7 (tujuh) kursi di DPRD Kabupaten Bangkalan, maka secara subtansi pencalonan Bupati dan Wakil Bupati Kabupaten bangkalan oleh DPC Partai Persatuan Nasional kabupaten Bangkalan tidak bertentangan dengan ketentuan Pasal 59 ayat (1) dan (2) Undang-Undang Nomor 12 Tahun 2008 tentang perubahan atas Undang-Undang Nomor 32 Tahun 2004 tentang Pemerintahan Daerah dan Pasal 4 
Peraturan Komisi Pemilihan Umum Nomor 6 tahun 2011 tentang Tata Cara Pencalonan Pemilihan Umum Kepala Daerah dan Wakil Kepala Daerah menetapkan: Bahwa pasangan calon Kepala Daerah dan wakil Kepala Daerah dapat dicalonkan baik oleh partai politik atau gabungan partai politik yang memperoleh paling sedikit $15 \%$ (lima belas perseratus) dari jumlah kursi di DPRD, dan atau memperoleh dukungan suara dalam Pemilu Ligislatif paling sedikit 15\% (lima belas perseratus) dari akumulasi perolehan suara sah dalam pemilu anggota DPRD di daerah yang bersangkutan.

Majelis Hakim megacu pada pendapat saksi M. Rokib bahwa PKNU memiliki 5 (lima) kursi di DPRD Kabupaten Bangkalan dan Partai Persatuan Daerah (PPD) memiliki 2 kursi di DPRD Kabupaten Bangkalan. Sedangkan jumlah seluruh anggota DPRD di Kabupaten Bangkalan sebanyak 45 (empat puluh lima) orang. Juga Majelis Hakim Mengacu pada keterangan saksi Tajul Anwar bahwa oleh karena jumlah anggota DPRD di Kabupaten Bangkalan sebanyak 45 (empat puluh lima) orang, maka syarat minimal 15\% (lima belas perseratus) suara partai pengusung dibulatkan menjadi minimal 7 (tujuh) kursi di DPRD. Selanjutnya diterangkan bahwa oleh karena jumlah kursi PKNU ditambah PPD (saat ini menjadi PPN) memiliki 7 (tujuh) kursi di DPRD Kabupaten Bangkalan, maka telah memenuhi persyaratan untuk mengusung calon Bupati dan Wakil Bupati Kabupaten Bangkalan. ${ }^{19}$

Secara prosedur bahwa tergugat tidak terlebih dahulu melakukan klarifikasi kepada Dewan Pimpinan Pusat Partai Persatuan Nasional sesuai AD/ART dan tidak meminta rekomendasi dewan pimpinan wilayah/daerah dan atau dewan pusat Partai Persatuan Nasional terkait dewan pimpinan Cabang Partai Persatuan Nasional Kabupaten Bangkalan yang dinyatakan sah dan bakal pasangan calon yang direkomendasikan sesuai

\footnotetext{
${ }^{19}$ Pengadilan Tata Usaha Negara Surabaya, Berkas Putusan Perkara Sengketa Tata Usaha Negara Nomor: 136/G/20/2/PTUN.SBY.,84-85.
} 
dengan Pasal 57 ayat (3) Peraturan KPU Nomor 6 Tahun 2011 tentang Tata Cara Pencalonan Pemilihan Umum Kepala Daerah dan Kepala Daerah, menetapkan:

"bahwa apabila dalam proses penelitian administrasi terhadap surat pencalonan ditemukan dokumin partai politik memiliki 2 (dua) atau lebih kepengurusan yang masing-masing mengajukan bakal pasangan calon yang berbeda atau bakal pasangan calon yang sama dalam Pemilu Bupati dan Wakil Bupati atau Walikota dan Wakil walikota, KPU Kabupaten/Kota melakukan klarifikasi kepada dewan pimpinan wilaya/daerah dan atau dewan pimpinan pusat partai politik sesuai AD/ART partai politik yang bersangkutan dan meminta rekomendasi dewan pimpinan cabang partai politik yang dinyatakan sah dan bakal pasangan calon yang direkomendasikan".

Maka Majelis Hakim berpendapat bahwa secara prosedural tindakan Tergugat dengan menerbitkan kedua Obyek sengketa $a$ quo adalah bertentangan dengan peraturan perundang-undangan yang berlaku khususnya Pasal 57 ayat (3) Peraturan KPU Nomor 6 Tahun 2011, serta bertentangan dengan asas kecermatan, asas kehati-hatian dan asas proposionalisme dari asas umum pemerintahan yang baik. ${ }^{20}$ Karena penerbitan kedua obyek sengketa $a$ quo khususnya yang menyangkut pencalonan K.H Imam Buchori dan HR. Zainal Alim sebagai calon Bupati dan Wakil Bupati Kabupaten Bangkalan mengandung cacat hukum dibidang prosedur, maka cukup beralasan hukum kiranya apabila gugatan Penggugat dikabulkan dan menyatakan batal kedua obyek sengketa aquo serta mewajibkan kepada Tergugat untuk mencabut kedua obyek sengketa aquo sepanjang mengenai pencalonan K.H Imam Buchori dan HR. Zainal Alim sebagai calon Bupati dan Wakil Bupati Kabupaten Bangkalan.

20 Pengadilan Tata Usaha Negara Surabaya, Berkas Putusan Perkara Sengketa Tata Usaha Negara Nomor: 136/G/2012/PTUN.SBY., 91. 
Majelis Hakim juga mengacu pada pendapat saksi ahli Safi, $\mathrm{SH}, \mathrm{MH}$ (Dosen FH Universitas Trunujoyo Madura) yang mengatakan bahwa kepengurusan Supardi sebagai Ketua dan Husnan Ahmad sebagai Sekretaris DPC Partai Persatuan Nasional Kabupaten Bangkalan yang merupakan bentukan dari Dewan Pimpinan Pusat Partai Persatuan Nasional tanpa adanya Konfercap adalah tidak sesuai dengan Pasal 23 ayat (1) UndanUndang Nomor 2 Tahun 2011 tentang Perubahan atas UndangUndang Nomor 2 Tahun 2008 tentang Partai Politik yang menyatakan: "Pergantian kepengurusan Partai Politik di setiap tingkatan dilakukan sesuai dengan AD dan ART", serta tidak sesuai dengan Pasal 22 ayat (2) huruf b Anggaran Dasar Partai Persatuan Nasional yang menetapkan: "Konferensi Cabang (Konfercab) b. Konferensi Cabang berwenang: Menetapkan program kerja Dewan Pimpinan Cabang, menilai laporan pertanggungjawaban Dewan Pimpinan Cabang, memilih dan menetapkan Ketua Dewan Pimpinan Cabang dan anggota formatur, ketua terpilih menjadi Ketua formatur, menetapkan keputusan lainnya" ${ }^{21}$

Atas dasar Pasal 23 ayat (1) Undang-Undang Nomor 2 Tahun 2011 tentang Perubahan atas Undang-Undang Nomor 2 Tahun 2008 tentang Partai Politik dan Pasal 22 ayat (2) huruf b Anggaran Dasar Partai Persatuan Nasional, maka pencalonan Bupati dan Wakil Bupati mengandung cacat hukum, sehingga dengan demikian usulan calon Bupati dan Wakil Bupati yang ditanda tangani oleh Supardi dan Husnan Amd secara otomatis juga mengandung cacat hukum. Dan majelis hakim menyatakan sependapat dengan pendapat ahli dan menjadikannya sebagai pendapat Majelis.

Majelis Hakim juga mengacu pada keterangan saksi M. Rokib dan $\mathrm{Hj}$. Siti Fathonah Rahmaniah dipersidangan diterangkan bahwa para saksi tidak mengetahui telah dilakukan pergantian

${ }^{21}$ AD/ART Partai Persatuan Nasional.

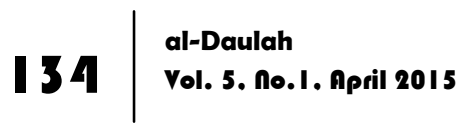


pengurus DPC Partai Persatuan Nasional Kabupaten Bangkalan karena tidak pernah diadakan konfercab atau nama lain dari padanya.

\section{Analisis terhadap Prosedur Pengajuan Cabup Cawabup Kab. Bangkalan Madura}

Sebagaimana penulis telah sampaikan sebelumnya bahwasaya Pasangan Calon Bupati dan Wakil Bupati Nomor urut 1 (satu) K.H. Imam Buchori dan HR. Zainal Alim diusung oleh gabungan partai politik yaitu Partai Kebangkitan Nasional Ulama (PKNU) yang memiliki 5 (lima) kursi di DPRD Kabupaten Bangkalan dan Partai Persatuan Nasional (PPN) yang memiliki 2 (dua) kursi di DPRD Kabupaten Bangkalan. Sedangkan jumlah seluruh anggota DPRD di Kabupaten Bangkalan adalah berjumlah 45 (empat lima) orang, maka sarat minimal 15\% (lima belas perseratus) suara partai politik pengusung dibulatkan menjadi minimal 7 (tujuh) kursi di DPRD. Oleh karena jumlah kursi PKNU ditambah PPD (saat ini menjadi PPN) memiliki 7 (tujuh) kursi di DPRD Kabupaten Bangkalan, maka telah memenuhi persyaratan untuk mengusung calon bupati dan wakil Bupati Kabupaten Bangkalan. ${ }^{22}$

Dengan demikian proses pencalonan Calon Nomor Urut 1 (satu) K.H. Imam Buchori dan HR. Zainal Alim telah sesuai dengan Pasal 4 Pragraf 1 huruf a dan b Peraturan Komisi Pemilihan Umum (KPU) No. 6 Tahun 2011 dan Undang-Undang Nomor 12 Tahun 2008 tentang perubahan atas Undang-Undang Nomor 32 Tahun 2004 tentang Pemerintahan Daerah menetapkan bahwa Partai politik atau gabungan partai politik dapat mendaftarkan bakal pasangan calon, apabila memenuhi persyaratan memperoleh kursi pada Pemilu Anggota DPRD Tahun 2009 paling sedikit 15\% (lima belas perseratus) dari jumlah kursi DPRD yang bersangkutan; atau memperoleh suara sah pada

\footnotetext{
22 Pengadilan Tata Usaha Negara Surabaya, Berkas Putusan Perkara Sengketa Tata Usaha Negara Nomor: 136/G/20/2/PTUN.SBY, 84-85.
}

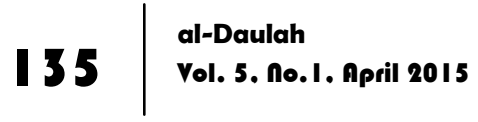


Pemilu Anggota DPRD Tahun 2009 paling sedikit 15\% (lima belas perseratus) dari akumulasi perolehan suara sah dalam Pemilu Anggota DPRD di daerah yang bersangkutan. ${ }^{23}$

Pasangan Calon Bupati dan Wakil Bupati Nomor urut 1 (satu) telah sesuai dengan surat Ketua DPC Partai Persatuan Nasional (DPC PPN) Kabupaten Bangkalan Nomor: 05/DPCPPN/BKLN/2012 tanggal 02 Juli 2012, Perihal: Perubahan Nama Partai dan SK Perubahan DPC PPN yang dilampiri dengan: Copy Lembaran Negara RI No. 7 Tahun 2012; Copy Keputusan Menteri Hukum dan Ham Republik Indonesia, No. M.HH-04.AH.11.01 Tahun 2012, tentang Pengesahan Anggaran Dasar, Susunan Kepengurusan Partai Persatuan Daerah menjadi Paertai Persatuan Nasional Pereode 2011-2016; Copy Akte Notaris Perubahan Nama Partai; SK DPP PPN, No. 01/SK/DPP-PPN/K-K.16/VI/2012, tentang: Susunan Dewan Pimpinan Cabang Partai Persatuan Nasional (DPC PPN) Kabupaten Bangkalan, dengan Ketua Sdr. Supardi dan Sekretaris Sdr. Husnan Amd.

Selain itu Pasangan Calon Bupati dan Wakil Bupati Nomor urut 1 (satu) telah menindaklanjuti pengajuan dari PPN dan PKNU sebagai partai pengusung sesuai dengan tahapan Pilkada dan peraturan perundang-undangan yang berlaku yang selanjutnya dituangkan dalam Berita Acara Nomor: 55/BA/X/2012 tanggal 22 Oktober 2012 tentang Penetapan Pasangan Calon Kepala Daerah dan Wakil Kepala Daerah Kabupaten Bangkalan Tahun 2012 dan Keputusan KPU Kabupaten Bangkalan Nomor 57/Kpts/KPUKab/014.329656/2012 tentang Penetapan Nomor Urut Pasangan Calon Kepala Daerah dan Wakil Kepala Daerah Sebagai Peserta Pemilihan Umum Kepala Daerah dan Wakil Kepala Daerah Kabupaten Bangkalan Tahun 2012 tanggal 24 Oktober 2012. Dan telah ikut melaksanakan tahapan Pilkada Kabupaten

${ }^{23}$ Peraturan KPU No. 6 Tahun 20II Tentang Tata Cara Pencalonan Pemilihan Umum Kepela Daerah dan Wakil Kepala Daerah, dan UU No. 12/2008 tentang perubahan atas UU No. 32/2004 tentang Pemerintahan Daerah. 
Bangkalan sebagaimana ketentuan perundang-undangan yang berlaku terutama telah melakukan kampanye yang telah mengeluarkan biaya yang tidak sedikit.

Dari pemaparan tersebut diatas, bahwa prosedur pencalonan Cabup Cawabup Kabupaten Bangkalan Madura menurut penelitian dan hemat penulis sepaham dengan pertimbangan Hakim PTUN Surabaya, bahwa dalam Pengajuan Cabup Cawabup Kab. Bangkalan Madura itu terdapat 2 (dua) pandangan yaitu: dari segi subtansi dan prosedur. ${ }^{24}$

Pertama dari segi subtansi Partai Persatuan Nasional bukanlah partai baru melaikan perubahan nama dari Partai Persatuan Daerah yang telah mengikuti Pemilu Anggota DPRD Tahun 2009 dan bersama PKNU yang juga peserta Pemilu Anggota DPRD Tahun 2009 dengan memiliki 7 (tujuh) kursi di DPRD Kabupaten Bangkalan, maka secara subtansi pencalonan Bupati dan Wakil Bupati Kabupaten bangkalan oleh DPC Partai Persatuan Nasional kabupaten Bangkalan tidak bertentangan dengan ketentuan Pasal 59 ayat (1) dan (2) Undang-Undang Nomor 12 Tahun 2008 tentang perubahan atas Undang-Undang Nomor 32 Tahun 2004 tentang Pemerintahan Daerah dan Pasal 4 Peraturan Komisi Pemilihan Umum Nomor 6 tahun 2011 tentang Tata Cara Pencalonan Pemilihan Umum Kepala Daerah dan Wakil Kepala Daerah.

Kedua dari segi prosedur penerbitan kedua obyek sengketa, bahwa usulan Colon Bupati dan Wakil Bupati Bangkalan yang ditandatangani oleh pimpinan Partai DPC Partai Persatuan Nasional merupakan Pimpinan Partai yang tidak sesuai dengan peraturan perundang-undangan yang berlaku yakni Pasal 1 angka 12 Peraturan KPU Nomor 6 Tahun 2011 Tentang Tata Cara Pencalonan Pemilihan Umum Kepala Daerah dan wakil Kepala Daerah. Karena partai Persatuan Nasional bukanlah partai baru namun hanyalah perubahan nama dari Partai Persatuan Daerah

\footnotetext{
${ }^{24}$ Indaryadi, SH. M.H., Wawancara dengan Hakim Ketua majelis pada tanggal 2 I Maret 2013.
}

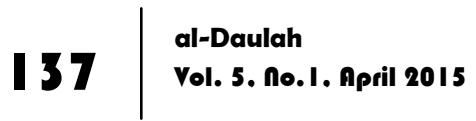


serta perubahan sebagaimana dituangkan dalam SK Menkumham RI No. M.HH-04.AH.11.01 TAHUN 2012 tanggal 9 Januari 2012 tidak merubah kepengurusan pada tingkat DPC.

Oleh karenanya Penggugat seharusnya secara otomatis tetap sebagai ketua dan sekretaris DPC Partai Persatuan Nasional Kabupaten Bangkalan namun faktanya berdasarkan saksi $\mathrm{H}$. Imam Buchori adalah H.M. Mukhlis Alkomi sebagai wakil ketua dan Ahmad Rois sebagai wakil sekretaris. Terhadap fakta hukum tersebut, saksi ahli Safi, SH. MH berpendapat bahwa jikapun dilakukan pergantian pengurus DPC Partai Persatuan Nasional Kabupaten Bangkalan oleh DPP Partai Persatuan Nasional, maka oleh karena Partai Persatuan Nasional bukan merupakan Partai yang baru berdiri, namun perubahan dari Partai Pesatuan Daerah, maka sesuai dengan Anggaran Dasarnya khususnya pada Pasal 22 ayat (2) huruf $b$, maka pergantian pengurus adalah sah apabila dilakukan melalui mekanisme Konfercab, namun hal tersebut tidak pernah dilakukan.

\section{Analisis terhadap Dasar Hukum Pertimbangan Majelis Hakim PTUN Surabaya No. 136/G/2012/PTUN. Sby perihal Diskualifikasi Cabup Cawabup Kabupaten Bangkalan Madura}

Salah satu kekuasaan absolut yang dimiliki Pengadilan Tata Uasaha Negara adalah memerikasa, memutuskan, dan menyelesaikan sengkata tata usaha negara. Adapun yang dimaksud dengan sengkata tata usaha negara yaitu sengketa yang timbul dalam bidang tata usaha negara, baik dipusat maupun di daerah, sebagai akibat dikeluarkannya keputusan tata usaha negara, termasuk sengketa kepegawaian. Hal ini sebagaimana telah diatur dalam Pasal 1 angka 4 Undang-Undang No. 5 Tahun 1986 tentang Peradilan Tata Usaha Negara diatas. ${ }^{25}$

Kasus yang termaktub dalam putusan Pengadilan Tata Usaha Negara Surabaya Nomor: 136/G/2012/PTUN.Sby. sebenarnya

25 Philipus M. Hadjon, Pengantar Hukum Administrasi Indonesia, (Yogyakarta: Gajah Mada University Press, Cet. 10. 2008), 318. 
antara penggugat dan tergugat itu berawal dari internal partai yang mengusung pasangan calon nomor urut 1 (satu) K.H Imam Buchori dan HR. Zainal Alim. Masalah yang timbul adalah bahawa, penggugat adalah partai yang ikut dalam Pemilu Legislatif Tahun 2009 dan kepengurusan di Kabupaten Bangkalan periode 2008 sampai saat ini di pegang oleh H.M. Mukhlis Alkomi, S.Pd selaku ketua dan Ahmad Rois sebagai Sekretaris akan tetapi ternyata dalam perjalanannya ada pihak yang mengaku sebagai pengurus cabang dari Partai persatuan Nasional Kabupaten Bangkalan dengan mengusung calon bupati atau wakil bupati pasangan K.>H Imam Buchori dan HR. Zainal Alim.

Kerugian yang diderita Penggugat sangat besar dan signifikan, tidak hanya kerugian materil, energy dan pikiran tetapi hak-hak para penggugat sebagai partai yang mempunyai 2 (dua kursi di DPRD Kabupaten Bangkalan seharusnya mendapatkan rasa keadilan dan kepastian hukum dalam proses pemilihan. Sehingga penggugat akhirnya mengajukan gugatannya ke PTUN Surabaya demi mendapatkan keadilan dan kepastian hukum.

Kemudian tergugat hingga diajukan gugatan ini tidak menyetujui atau menolak terhadap gugatan yang di ajukan penggugat karena tergugat dalam perjalannya sudah sesuai dengan Peraturan Perundang-undangan dan memenuhi Anggaran Dasar (AD) Anggaran Rumah Tangga (ART).

Dalam perkara mengenai sengketa Tata Usaha negara ini penulis teliti, Majelis Hakim Pengadilan Tata Usaha Negara Surabaya mengadili dan memutus perkara mengabulkan gugatan Penggugat untuk sebagian dan menyatakan batal kedua obyek sengketa a quo Tergugat serta mewajibkan kepada Tergugat untuk mencabut kedua obyek sengketa a quo sepanjang mengenai pencalonan K.H Imam Buchori dan HR. Zainal Alim sebagai calon Bupati dan Wakil Bupati Kabupaten Bangkalan. Menolak gugatan pengugat untuk selebihnya dan menghukum Tergugat untuk membayar biaya perkara sebesar Rp 152.500, (Seratus Lima Puluh Dua Ribu Lima Ratus Rupiah). 
Majelis Hakim dalam memutuskan perkara tersebut mangacu pada pertimbangan dan undang-dang yang berlaku, bahwa tergugat tidak terlebih dahulu melakukan klarifikasi kepada Dewan Pimpinan Pusat Partai Persatuan Nasional sesuai AD/ART dan tidak meminta rekomendasi dewan pimpinan wilayah/daerah dan atau dewan pusat Partai Persatuan Nasional terkait dewan pimpinan Cabang Partai Persatuan Nasional Kabupaten Bangkalan yang dinyatakan sah dan bakal pasangan calon yang direkomendasikan sesuai dengan Pasal 1 angka 12 Pasal 57 ayat (3) Peraturan KPU Nomor 6 Tahun 2011 tentang Tata Cara Pencalonan Pemilihan Umum Kepala Daerah dan Wakil Kepala Daerah. Maka Majelis Hakim berpendapat bahwa secara prosedural tindakan Tergugat dengan menerbitkan kedua Obyek sengketa $a$ quo adalah bertentangan dengan peraturan perundangundangan yang berlaku khususnya Pasal 1 angka 12 Pasal 57 ayat (3) Peraturan KPU Nomor 6 Tahun 2011. Serta bertentangan dengan asas kecermatan, asas kehati-hatian dan asas proposionalisme dari asas umum pemerintahan yang baik.

Karena penerbitan kedua obyek sengketa a quo khususnya yang menyangkut pencalonan K.H Imam Buchori dan HR. Zainal Alim sebagai calon Bupati dan Wakil Bupati Kabupaten Bangkalan mengandung cacat hukum dibidang prosedur, maka cukup beralasan hukum kiranya apabila gugatan Penggugat dikabulkan dan menyatakan batal kedua obyek sengketa a quo serta mewajibkan kepada Tergugat untuk mencabut kedua obyek sengketa a quo sepanjang mengenai pencalonan K.H Imam Buchori dan HR. Zainal Alim sebagai calon Bupati dan Wakil Bupati Kabupaten Bangkalan.

Majelis Hakim juga mengacu pada pendapat saksi ahli Safi, $\mathrm{SH}, \mathrm{MH}$ (Dosen FH Universitas Trunujoyo Madura) yang mengatakan bahwa kepengurusan Supardi sebagai Ketua dan Husnan Ahmad sebagai Sekretaris DPC Partai Persatuan Nasional Kabupaten Bangkalan yang merupakan bentukan dari Dewan Pimpinan Pusat Partai Persatuan Nasional tanpa adanya 
Konfercap adalah tidak sesuai dengan Pasal 23 ayat (1) UndanUndang Nomor 2 Tahun 2011 tentang Perubahan atas UndangUndang Nomor 2 Tahun 2008 tentang Partai Politik serta tidak sesuai dengan Pasal 22 ayat (2) huruf b Anggaran Dasar Partai Persatuan Nasional oleh karenanya mengandung cacat hukum, sehingga dengan demikian usulan calon Bupati dan Wakil Bupati yang ditandatangani oleh Supardi dan Husnan Amd secara otomatis juga mengandung cacat hukum. Dan majelis hakim menyatakan sependapat dengan pendapat ahli dan menjadikannya sebagai pendapat Majelis.

Setelah melihat kronologi penyelesaian perkara sengketa Tata Usaha Negara dan juga melihat dasar pertimbangan hakim terhadap perkara tersebut diatas penulis berpendapat bahwa dalam memutuskan perkara sengka Tata Usaha Negara, Majelis Hakim Pengadilan Tata Usaha Negara Surabaya telah tepat dan sesuai dengan peraturan prundang-undang yang berlaku, dan untuk menguatkan peneafsiran hukum yang lebih jelas Majelis Hakim mengacu pada ketarangan saksi ahli, karena putusan hakim yang memakai dasar keterangan saksi ahli dan pendapat para tokoh itu artinya untuk lebih mengetahui penafsiran hukum yang lebih jelas dalam proses peradilan. ${ }^{26}$

Juga salah satu dari kewengan Pengadilan Tata Usaha Negara Surabaya adalah Pasal 53 ayat (1) dan (2) Undang-Undang No. 9 Tahun 2004 tentang perubahan atas Undang-Undang No. 5 Tahun 1986 tentang Peradilan Tata Usaha Negara yang menyatakan.

(1) orang atau badan hukum perdata yang merasa kepentingannya dirugikan oleh suatu Keputusan Tata Usaha Negara dapat mengajukan gugatan tertulis kepada Pengadilan yang berwenang yang berisi tuntutan agar Keputusan Tata Usaha Negara yang disengketakan itu dinyatakan batal atau tidak sah dengan atau tanpa disertai tuntutan ganti rugi dan/atau rehabilitas.

${ }^{26}$ Dialog dengan Nara sumber dalam Pelatihan Metodologi Penelitian dan Penulisan Hukum Bagi Mahasiswa Jurusan Siyasah Jinayah Fak. Syariah IAIN Surabaya pada tanggal 07 April 2013.

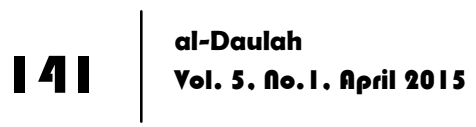


(2) alasan-alas an yang dapat digunakan dalam gugatan sebagai mana pada ayat (1) adalah:

a. Keputusan Tata Usaha Negara yang digugat itu bertentangan dengan peraturan perundang-undangan yang berlaku;

b. Keputusan Tata Usaha Negara yang digugat itu bertentangan dengan asas umum pemerintahan yang baik.

Analisis Fiqh Siyâsah terhadap Putusan PTUN No. 136/G/2012/PTUN.Sby Pprihal Diskualifikasi Cabup Cawabup Kab. Bangkalan Madura

Putusan PTUN Surabaya No. 362/G/2012/PTUN.Sby. tentang diskualifikasi Cabup Cawabup Kabupaten Bangkalan Madura nomor urut 1 (satu) K.H. Imam Buchori dan HR. Zainal Alim tidak begitu saja diterima oleh masyarakat. Sebab mereka menganggap bahwa mekanisme proses Cabup Cawabup Kabupaten Bangkalan nomor urut 1 (satu) yang diselenggarakan oleh KPUD telah sesuai dengan undang-undang yang berlaku. Jadi masyarakat meyakini dalam proses pencalonan itu sudah benar dan tidak bertentangan dengan undang-undang yang berlaku.

Selain itu masyarakat Bangkalan sangat antusias dan mendukung atas pencalonan K.H. Imam Buchori (sebagai Calon Bupati) hal ini disebabkan K.H. Imam Buchori terkenal alim ilmu agamanya, kemulyaan akhlaqnya, dan pendekatan serta pengayoman kepada masyarakat sangat erat dan telah dirasakan oleh masyarakat, dan mayoritas ulama Bangkalan mendukung atas pencalonan beliau (KH. Imam Buchori) sebagai Bupati Bangkalan. ${ }^{27}$

Bagi masyarakat pemimpin sangat dibutuhkan oleh umat, baik masyarakat kecil, apalagi masyarakat besar, khsusnya bagi masyarakat pedesaan Kepala daerah atau Bupati bukanlah sematamata hanya sebagai pemimpin formal tertinggi saja, akan tetapi di anggap juga sebagai bapak bagi seluruh penduduk desa bahkan

27 Zainal Abidin, Wawancara, 8 Januari 2013.

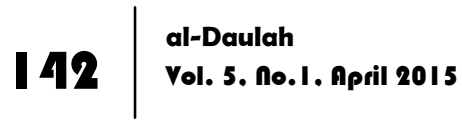


sering di sepadankan dengan raja karena dengan adanya pemimpin yang terpilih diharapkan menjadi panutan umat yang nantinya akan membawa mereka kejalan yang lebih baik dan tatanan yang lebih teratur, tenteram, aman dan jauh dari fitnah.

Prof. Sadu Wasistiono dalam bukunya Kapita Selekta Manajemen Pemerintahan daerah, mengatakan ada tiga hal yang perlu dipertimbangkan di dalam memilih pimpinan pemerintahan yang kemudian diharapkan akan menjadi pemimpin, yakni: kapabilitas, akseptabilitas serta kompatibilitas. Kapabilitas adalah gambaran kemampuan dari si pemimpin baik intelektual maupun moral, yang dapat dilihat dari catatan jejak (track record) pendidikannya maupun jejak sikap dan prilakunya selama ini. Pemimpin yang baik tidak akan muncul secara tiba-tiba, melainkan melalui suatu proses panjang. Sedangkan akseptabilitas adalah gambaran tingkat penerimaan pengikut terhadap kehadiran pemimpin. Kompatibilitas dimaksudkan sebagai kemampuan untuk menyesuaikan diri dengan kebijakan dari pemerintah tingkat atasnya dan mengakomodasikan kebijakan dari pemerintah tingkat bawahnya maupun tuntutan dari para pengikutnya. ${ }^{28}$

Oleh sebab itulah Islam memberikan pedoman dalam memilih pemimpin yang baik Dalam Al Qur'an, Allah SWT memerintahkan ummat Islam untuk memilih pemimpin yang baik dan beriman, sebagaimana firman Allah dalam (Q.S. At Taubah: 9 ayat 23).

"Hai orang-orang yang beriman Janganlah kamu jadikan bapak-bapak dan saudara-saudaramu menjadi pemimpinpemimpinmu, jika mereka lebih mengutamakan kekafiran atas keimanan. Dan siapa di antara kamu menjadikan mereka menjadi pemimpin, maka mereka itulah orang-orang yang zalim". ${ }^{29}$

${ }^{28}$ Sadu Wasistiono, Kapita Selekta Manajemen Pemerintahan Daerah, (Bandung: CV. Fokus media, 2003), II8.

${ }^{29}$ Depag. RI., Al-Qur'an dan Terjemah, (Bandung: CV. Penerbit Jumatul 'Ali-ART,2005),88.

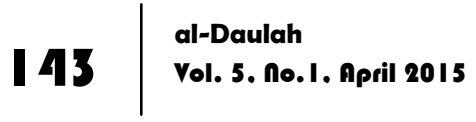


Mayoritas ulama sepakat mengenai keharusan menyelenggarakan siyâsah berdasarkan syara'. Dalam kajian Fiqh Siyâsah pengangkatan pemimpin untuk mengurusi perkara kaum muslimin ini mutlak harus dilaksanakan karena siyâsah didalamnya mengatur hubungan antara manusia dengan manusia, manusia dengan lembaga, lembaga dengan lembaga, maupun Negara dengan Negara dengan ketentuan syariat Islam. Pada uraian Ibnul Qayyim ketika mengutip pendapat Ibnu 'Aqil dalam kitab Al Funûn yang menyatakan, Siyâsah adalah tindakan yang dengan tindakan itu manusia dapat lebih dekat kepada kebaikan dan lebih jauh dari kerusakan meskipun tindakan itu tidak ada ketetapannya dari rasul dan tidak ada tuntunan wahyu yang diturunkan. ${ }^{30}$ Oleh karena itu perlu dilakukan suksesi selektif bagi orang-orang yang akan dipilih untuk memangku jabatan tersebut karena jabatan itu adalah sebuah amanat yang harus dilaksanakan sesuai dengan misi yang di embannya. Firman Allah dalam (Q.S Annisa': 4 ayat 85).

"Sesungguhnya Allah menyuruh kamu menyampaikan amanat kepada yang berhak menerimanya, dan (menyuruh kamu) apabila menetapkan hukum di antara manusia supaya kamu menetapkan dengan adil. Sesungguhnya Allah memberi pengajaran yang sebaik-baiknya kepadamu. Sesungguhnya Allah adalah Maha Mendengar lagi Maha Melihat". ${ }^{31}$

Sabda Nabi Muhammad Saw.

"Sesungguhnya ia adalah amanat. Dan pada hari kiamat ia merupakan kehinaan dan penyesalan, kecuali bagi mereka yang mengembalikannya sesuai dengan haknya dan melaksanakan apa yang menjadi tuntutannya" (HR...Muslim). ${ }^{32}$

30 Ibnul Qayyim Al Jauziyah, Al Thuruq Al-Hukmiyah Fi Siyâsat Al-Syarilyah, Tahqiq Basyir Muhammad Uyun,hlm, 26 dalam program kitab digital al-Maktabah asy-Syamilah, versi 2.09.

${ }^{31}$ Depag. RI., Al-Qur'an dan Terjemah., 92.

${ }^{32}$ H.R. Muslim, 305. 
Berdasarkan dalil diatas, maka Islam telah memberi konsep dalam memilih pemimpin yang baik sebagaimana penyusun lansir dari konsepnya al-Mawardi, hendaknya umat Islam di mana dan kapan saja memilih pemimpin yang memiliki integritas moral yang tinggi (jujur, amanah, berahlak baik, dan adil), memiliki ilmu dan wawasan yang luas, tidak cacat fisiknya, punya wawasan politik dan kemampuan mengatur rakyat, ahli strategi dan keberanian, ketabahan sampai pada tingkat sanggup mempertahankan kehormatan dan berjihad melawan musuh, dan mempunyai garis keturunan Quraisy.33 Syarat terakhir tidak dipandang sebagai suatu keharusan oleh pemikir-pemikir Sunni setelahnya dan penulis-penulis modern, sebab bertentangan dengan prinsip-prinsip Islam yang mengutamakan persamaan hak sesama muslim tanpa memandang asal-usul atau keturunan.

Mekanisme proses Cabup Cawabup Kabupaten Bangkalan nomor urut 1 (satu) yang diselenggarakan oleh KPUD secara subtansi telah sesuai dengan undang-undang yang berlaku yakni Pasal 4 Paragraf 1 huruf a dan b Peraturan Komisi Pemilihan Umum (KPU) No. 6 Tahun 2011 dan Undang-Undang Nomor 12 Tahun 2008 tentang perubahan atas Undang-Undang Nomor 32 Tahun 2004 tentang Pemerintahan Daerah dan tidak keluar dari ajaran Islam (syari'at), namun bersamaan dengan proses tersebut atas dasar dan pertimbangan Majelis Hakim PTUN Surabaya, sebagaimana penulis jelaskan pada penbahasan sebelumnya bahwa secara prosedural usulan Calon Bupati dan Wakil Bupati Bangkalan yang ditandatangani oleh pimpinan Partai DPC Partai Persatuan Nasional (Supardi dan Husnan Amd) merupakan Pimpinan Partai yang tidak sesuai dengan peraturan perundangundangan yang berlaku yaitu Pasal 1 angka 12 Pasal 57 ayat (3) Peraturan KPU Nomor 6 Tahun 2011. Serta bertentangan dengan asas kecermatan, asas kehati-hatian dan asas proposionalisme dari asas umum pemerintahan yang baik.

${ }^{33}$ Lihat al-Mawardi, al-Ahkam as-Sulthaniyah, 3-4.

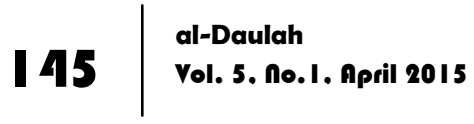


Begitu juga menurut saksi ahli Safi, SH, MH (Dosen FH Universitas Trunujoyo Madura) yang mengatakan bahwa usulan calon Bupati dan Wakil Bupati yang ditandatangani oleh Supardi dan Husnan Amd mengandung cacat hukum karena tidak sesuai dengan Pasal 23 ayat (1) Undan-Undang Nomor 2 Tahun 2011 tentang Perubahan atas Undang-Undang Nomor 2 Tahun 2008 tentang Partai Politik serta tidak sesuai dengan Pasal 22 ayat (2) huruf b Anggaran Dasar Partai Persatuan Nasional.

Dalam fiqh siyâsah dijelaskan sebagaimana yang dikatakan oleh Imam al-Mawardi bahwa jika kepemimpinan diberikan kepada dua orang di dua tempat, maka, menurut pendapat yang benar yang dianut oleh para fuqaha' (mayoritas ulama fiqh), bahwa kursi kepemimpinan diberkan kepada siapa yang diantara kedua orang tersebut yang paling dahulu pengangkatannya, dan akadnya (kesepakatannya). Permasalahan ini sama seperti kasus dua wali dalam pernikahan seorang wanita. Jika ada dua wali menikahkan seorang wanita dengan dua orang pria, maka pernikahan yang benar adalah pernikahan yang paling dahulu akadnya. Jika telah diketahui dengan jelas siapa yang lebh dahulu diangkat menjad pemimpn, maka kursi kepemimpinan menjadi miliknya, kemudian orang kedua harus menyerahkan segala urusan kepadanya, dan berbai'at kepadanya (pemimpin yang paling dahulu). ${ }^{34}$

Dalam siyâsah dusturiyah yang merupakan bagian dari figh siyâsah yang membahas masalah perundang-undangan negara agar sejalan dengan nilai-nilai syari'at. Sebab tujuan dibuatnya peraturan perundang-undangan adalah untuk mewujudkan kemaslahatan manusia dan untuk memenuhi kebutuhan manusia. Jika peraturan perundang-undangan tersebut tidak sejalan dengan tujuan syari'at islam dalam arti telah merugikan hak-hak rakyat. Maka dalam hal ini yang berwenang untuk memutus masalah ini

${ }^{34}$ Imam al-Mawardi, al-Ahkam as-Sulthaniya, 9.

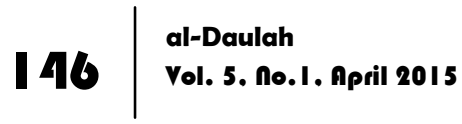


adalah lembaga yudikatif atau hakim (qâdi) yang mempunyai kewenangan masing-masing dalam memutuskan suatu perkara.

Menurut al-mawardi dalam kitab al-ahkâm as-sulthaniyyah salah satu dari kekuasaan hakim adalah memutuskan perselisihan, pertengkaran dan konflik, dengan mendamaikan kedua belah pihak yang berperkara secara suka rela, atau memaksa keduanya berdanai. Mengambil hak-hak dari orang-orang yang menundanya kemudian memberikannya kepada yang berhak menerimannya, setelah terbukti ia sebagai pemiliknya dengan dua hal; pengakuan dan barang bukti. ${ }^{35}$

Islam memerintahkan dalam menetapkan hukum diantara manusia haruslah berlaku adil, karena kedudukan berlaku adil adalah sebagai prinsip konstitusional dan sebagai poros politik keagamaan. Sebagaimana dituangkan dalam Surat An-Nisa' ayat 58. Allah berfirman:

"Sesungguhnya Allah menyuruh kamu menyampaikan amanat kepada yang berhak menerimanya, dan (menyuruh kamu) apabila menetapkan hukum di antara manusia supaya kamu menetapkan dengan adil. Sesungguhnya Allah memberi pengajaran yang sebaik-baiknya kepadamu. Sesungguhnya Allah adalah Maha Mendengar lagi Maha Melihat". ${ }^{36}$

Ayat di atas menjelaskan bahwa Allah memerintahkan untuk menunaikan amanat secara sempurna serta ditunaikan kepada pemiliknya atau yang berhak menerimanya, baik amanah yang menyangkut hak-hak Allah atas hambanya seperti shalat, zakat, puasa, dan sebagainya, maupun amanah manusia. Selain itu Allah memerintahkan ketika menetapkan hukum diantara manusia, baik yang berselisih dengan manusia lain atau tanpa perselisihan, maka kalau menetapkan putusan dengan adil sesuai dengan apa yang diajarkan oleh Allah SWT, yaitu tidak memihak kecuali kepada

\footnotetext{
${ }^{35}$ Lihat di bukunya al-Mawardi, al-Ahkam as-Sulthaniyah, 132

${ }^{36}$ Depag. RI., A/-Qur'an dan Terjemah, 92.
}

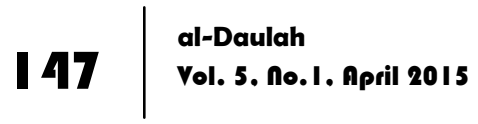


yang keberatan dan tidak pula menjatuhkan sanksi kecuali kepada yang melanggar.

Ketika seseorang mencalonkan sebagai Bupati dan Wakil Bupati, namun dalam proses pencalonannya oleh putusan pengadilan digagalkan karena tidak sesuai dengan peraturan perundang-undangan yang berlaku, maka ia harus menerima dan mentaati atas putusan pengadilan itu. Sebagaimana firman Allah SWT. dalam Surat An-Nisa' ayat 59 dan Hadits Rasulullah Saw.

"Hai orang-orang yang beriman, ta'atilah Allah dan ta'atilah Rasul (Nya), dan ulil amri di antara kamu. Kemudian jika kamu berlainan pendapat tentang sesuatu, maka kembalikanldh ia kepada Allah (Al-Qur'an) dan Rasul (sunnahnya), jika kamu benar-benar beriman kepada Allah dan hari kemudian. Yang demikian itu lebih utama (bagimu) dan lebih baik akibatnya." 37

"Hadits Abi Hurairah ra. bahwasanya Rasaulullah SAW. bersabda: "Barang siapa taat kepadaku, ia taat kepada Allah, dan barang siapa durhaka kepadaku, maka ia durhaka kepada Allah, dan barang siapa durhaka kepada pemimpinku, sungguh ia durhaka kepadaku." 38

Dari penjelasan di atas penulis menyimpulkan bahwa penyelesaian perkara sengketa Tata Usaha Negara No. 136/G/2012/PTUN. Sby. dan juga melihat dasar hukum pertimbangan hakim terhadap perkara tersebut di atas penulis berpendapat bahwa dalam memutuskan perkara sengka Tata Usaha Negara, Majelis Hakim Pengadilan Tata Usaha Negara Surabaya telah tepat dan sesuai dengan peraturan prundangundang yang berlaku, dan telah sesuai dengan syari'at (hukum) Islam.

${ }^{37}$ Depag. Rl., Al-Qur'an dan Terjemah, (Bandung: CV. Penerbit Jumatul 'Ali-ART, 2005), 88.

${ }^{38}$ HR. Bukhari, Sahih Bukhari, (Riyadh: al-Ma'arif, 2002 M), 284. 


\section{Penutup}

Prosedur pengajuan Cabup Cawabup Kabupaten Bangkalan Madura nomor urut satu K.H. Imam Buchori dan HR. Zainal Alim, secara subtansi adalah: telah sesuai dengan ketentuan Pasal 59 ayat (1) dan (2) UU No 12 Tahun 2008 tentang perubahan atas UU No. 32 Tahun 2004 dan Pasal 4 Peraturan KPU No. 6 Tahun 2011 dan telah menindaklanjuti Keputusan Ketua Partai Politik No. 05/DPC-PPN/BKLN/2012 dan Keputusan Menteri Hukum dan HAM No. M.HH-04.AH.11.01. Namun secara prosedur usulan Cabup Cawabup Kabupaten Bangkalan adalah cacat hukum karena tidak sesuai dengan Pasal 1 angka 12 Peraturan KPU No. 6 Tahun 2011 dan Pasal 22 ayat (2) huruf b AD ART Partai Persatuan Nasional.

Dasar hukum pertimbangan Hakim PTUN Surabaya dalam Putusan No. 136/G/2012/PTUN.Sby mengenai diskualifikasi Cabup Cawabup Kabupaten Bangkalan Madura, adalah bakal pasangan calon yang direkomendasikan oleh Pimpinan Partai Persatuan Nasional tidak sesuai dengan Pasal 1 angka 12 Pasal 57 ayat (3) Peraturan KPU No. 6 Tahun 2011 serta bertentangan dengan asas kecermatan, asas kehati-hatian dan asas proposionalisme dari asas umum pemerintahan yang baik.

Putusan PTUN Surabaya mengenai diskualifikasi Cabub Cawabup Kabupaten Bangkalan Madura menurut Fiqh Siyâsah adalah benar dan sesuai dengan hukum Islam yang menjelaskan bahwa jika ada dua kepemimpinan dalam suatu organisasi maka kepemimpinan itu diberikan kepada orang yang lebih dahulu pengangkatannya. Hal ini sesuai dengan pendapat imam $\mathrm{Al}$ mawardi dalam kitab al-Ahkam as-Sulthaniyah mengatakan bahwa "jika ada dua kepemimpinan di satu tempat maka menurut mayoritas ulama fiqh bahwa kursi kepemimpinan harus diberikan kepada siapa yang diantara kedua orang tersebut yang paling dahulu pengangkatannya dan akadnya". 


\section{Daftar Pustaka}

Abidin, Zainal. Wawancara, 8 Januari 2013.

Bukhari (al-). Sahih Bukhari. Riyadh: al-Ma'arif, 2002.

Depag. RI. Al-Qur'an dan Terjemah. Bandung: CV. Penerbit Jumatul 'Ali-ART, 2005.

Djohan, Djohermansyah. "Pilkada, Jangan Ditunda", Artikel Media Indonesia, 10 januari 2005.

Hadjon, Philipus M. Pengantar Hukum Administrasi Indonesia. Yogyakarta: Gajah Mada University Press, Cet. 10, 2008.

Hakim, Sudartono Abdul. Islam Berbagai Aspek. Yogyakarta: LPMI, 1995.

Indaryadi. Wawancara, 21 Maret 2013.

Jauziyah (al-), Ibnul Qayyim. Al Thuruq Al-Hukmiyah Fi Siyâsat AlSyar'iyah. Tahqiq Basyir Muhammad Uyun, dalam program kitab digital al-Maktabah asy-Syamilah, versi 2.09.

Keputusan Mahkamah Konstitusi Tentang Putusan Perkara No. 072-073/PUU-II/2005 "Pengujian Undang-Undang Nomor 32 Tahun 2004 Tentang Pemerintahan Daerah Terhadap UUD 1945".

Mahkamah Konstitusi Republik Indonesia. Berkas Putusan Perkara Sengketa Perselisihan Hasil Pemilihan Umum Kepala Daerah dan

Wakil Kepala Daerah Kabupaten Bangkalan Tahun 2012 Nomor : 101/PHPUDX/2012.

Mawardi (al-). al-Ahkam as-Sulthaniyah. alih bahasa, Fadil Bahri, dalam Hukum-Hukum Penyelenggaraan Negara Dalam Syari'at Islam. Jakarta: Darul Falah, Cet. II, 2006.

Pengadilan Tata Usaha Negara Surabaya. Berkas Putusan Perkara Sengketa Tata Usaha Negara Nomor: 136/G/2012/PTUN.SBY.

Peraturan KPU No. 6 Tahun 2011 Tentang Tata Cara Pencalonan Pemilihan Umum Kepela Daerah dan Wakil Kepala Daerah, dan UU No. 12/2008 tentang perubahan atas UU No. 32/2004 tentang Pemerintahan Daerah. 
Salossa, Daniel S. Mekanisme, Persyaratan,dan Tata Cara Pilkada Langsung Menurut Undang-Undang No. \#32 Th 2004 tentang Pemerintahan Daerah. Yogyakarta: Media Pressndo, 2005.

Suharizal. Pemilukada Regulasi, Dinamika dan Konsep Mendatang. Jakarta: PT. RajaGrafindo Persada, 2012.

Supriyanto, Didik. Menjaga Independensi Penyelenggara Pemilu disertai Undang-Undang Nomor 22 Tahun 2007 Tentang Penyelenggara Pemilu. Jakarta: Perludem, 2007.

T., Titik Triwulan, dan Kombespol. Ismu Gunadi Widodo. Hukum Tata Usaha Negara dan Hukum Acara Peradilan Tata Usaha Negara Indonesia. Jakarta: Kencana Media Group, 2011.

--------. Pemilihan Kepala Daerah Berdasarkan Undang-Undang No.32 Tahun 2004 dalam Sistem Pemilu Menurut UUD 1945. Jakarta: Prestasi Pustaka Publisher, 2005.

UU No. 12 Tahun 2008 tentang perubahan atas UU No. 32 tahun 2004 tentang Pemerintahan Daerah.

Wasistiono, Sadu. Kapita Selekta Manajemen Pemerintahan Daerah. Bandung: CV. Fokusmedia, 2003.

Widjaja, Haw. Otonomi Daerah dan Daerah Otonomi. Jakata: PT. RajaGrafindo Persada, 2002.

Zuhaili (az-), Wahbah. Al Fiqhul Islami Wa Adillatuh. Beirut: Darul Fikri, Vol 8, 1997. 